\title{
RUNCINA SETOENSIS, A NEW AND RARE SPECIES FROM THE COAST OF KII, MIDDLE JAPAN (OPISTHOBRANCHIA)
}

\author{
$\operatorname{AUTHOR}(\mathrm{S}):$ \\ Baba, Kikutaro
}

\section{CITATION:}

Baba, Kikutaro. RUNCINA SETOENSIS, A NEW AND RARE SPECIES FROM THE COAST OF KII, MIDDLE JAPAN (OPISTHOBRANCHIA). PUBLICATIONS OF THE SETO MARINE BIOLOGICAL LABORATORY 1954, 3(3): 373-374

ISSUE DATE:

1954-05-30

URL:

http://hdl.handle.net/2433/174484

RIGHT: 


\title{
RUNCINA SETOENSIS, A NEW AND RARE SPECIES FROM THE COAST OF KII, MIDDLE JAPAN (OPISTHOBRANCHIA) $)^{\text {?) }}$
}

\author{
KiKUTARô BABA \\ Biological Laboratory, Osaka University of Liberal Arts
}

\begin{abstract}
With one Text-figure
The genus Runcina (=Pelta) is a small group of the opisthobranchiate Order Cephalaspidea. The animals are mostly very small in size, too. The first record of the genus from our territory was made by me in 1937 (Runcina elioti BABA, from Amakusa). The present paper deals with the second form for which I am here going to give a new specific name. I am very glad to thank Dr. Huzio UTINomr, of the Seto Marine Biological Laboratory, for the kindness shown to me in studying this rare and interesting species at Seto.
\end{abstract}

\section{Runcina setoensis BABA n. sp. \\ Kurohime-umiushi (new name)}

(Fig. 1)

Animal limaciform, elongate, 3-7 $\mathrm{mm}$ in length, the foot projecting behind the mantle, no oral tentacles. Entirely smooth above. Head shallowly bilobed in front, with sessile eyes shining through the skin; the haliotiform shell wholly concealed in the posterior part of the mantle, whitish and much reduced. Anus behind the end of the mantle, median in position; a gill consisting of about 4 lamellae just to the right of the anus. General colour blackish, darker towards the median part, the back sprinkled everywhere with minute brown spots. A submarginal band of ashy yellow running round the mantle excepting at the fore end of the head. Foot sole dirty yellowish covered with minute brown spots as above. Gill blackish. Jaw-plates paired, their surface closely beset with rod-like elements. Radula formula (?). The radulae in my specimens always showed marked tendency of degeneration and were very difficult to count the numbers of the elements composing them. Gizzard as usual armed with 4 chitinous plates.

1) Contributions from the Seto Marine Biological Laboratory, No. 228.

Publ. Seto Mar. Biol. Lab., III (3), 1954. (Article 29) 

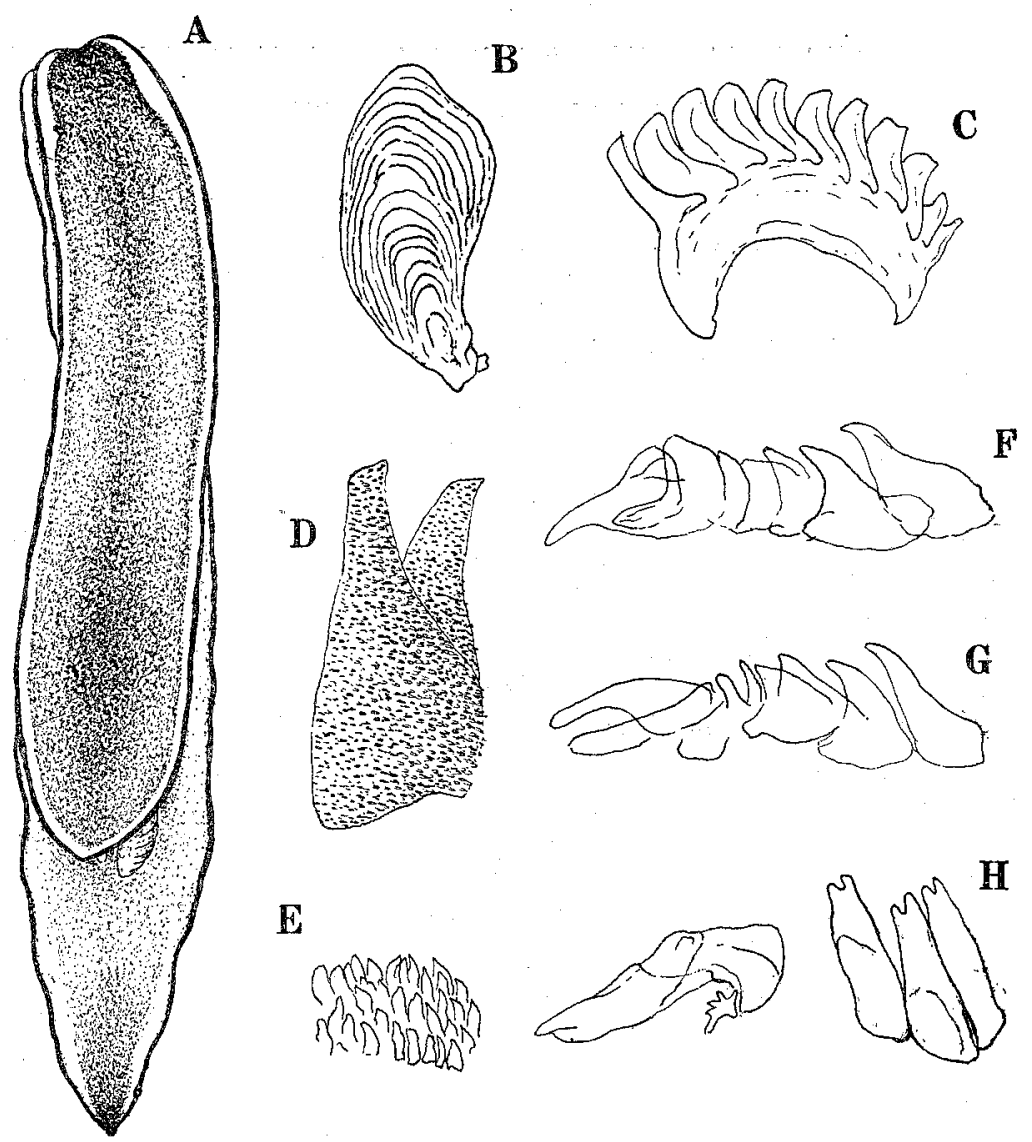

Fig. 1. Runcina setoensis n. sp.

A. Animal (Seto, Jan. 4, 1951. Total length $5 \mathrm{~mm})$; B. Shell $(\times 110)$; C. Chitinous plate of gizzard $(\times 150)$; D. Jaw-plates $(\times 300)$; E. Elements of jaw-plate $(\times 600)$; F-H. All of the radula teeth in 3 different specimens $(\times 600)$.

Loc.: Seto, Kii, underneath the pebbles in the tide pools of high water level (Jan. and Mar. 1951; Jan. and Apr. 1953; only 12 sps., coll. by Mr. Iwao Hamatani and the present writer).

The present new species is distinct in colours and in having much reduced radula teeth.

\section{LITERATURE}

BABA, K. 1937. Opisthobranchia of Japan (I). Journ. Dept. Agric. Kyûshâ Imp. Univ., vol. 5, no. 4. 